Gut, 1978, 19, 233-239

\title{
Serum and faecal lysozyme in inflammatory bowel disease
}

\author{
H. J. KLASS ${ }^{1}$ AND G. NEALE ${ }^{2}$ \\ From the Department of Gastroenterology, Hammersmith Hospital, London
}

SUMMARY Lysozyme (EC 3.2.1.17) concentrations were measured in the serum and stools of patients with inflammatory bowel disease and compared with the concentrations in similar material from normal controls, patients with non-inflammatory gastrointestinal disease, and patients without gastrointestinal disease. By the turbidometric method, values of lysozyme $(\mu \mathrm{g} / \mathrm{ml} \pm \mathrm{SD})$ are considerably greater in the serum of patients with active Crohn's disease $(9 \cdot 2 \pm 2 \cdot 7)$ than in the serum of healthy controls $(4 \cdot 4 \pm 2 \cdot 0)$. They do not, however, distinguish individual patients with Crohn's disease from those with ulcerative colitis nor from those with a variety of other gastrointestinal conditions. The lysoplate method gives much higher values for serum lysozyme than the turbidometric method but there is a considerable overlap between the results for patients with Crohn's disease $(60 \cdot 1 \pm 30 \cdot 7)$ and normal controls $(27 \cdot 4 \pm 17 \cdot 5)$. There is only a moderate correlation between the results given by the two methods $(r=0.56)$ and it is suggested that factors other than enzyme activity and methodological variation are responsible for the observed differences. This is supported by the finding that, with Crohn's disease in remission, serum lysozyme values (lysoplate) return to normal values but with the turbidometric method remain raised. Mean faecal lysozyme levels, expressed either as a concentration or as total daily excretion, in patients with inflammatory bowel disease are very significantly greater than values in healthy controls and in diseased subjects without diarrhoea but are not significantly different from those subjects with other causes of diarrhoea.

In 1974 serum lysozyme was reported to be raised in a proportion of patients with active Crohn's disease and ulcerative colitis (Kane et al., 1974). The following year evidence was published suggesting that serum lysozyme was raised in Crohn's disease but not in ulcerative colitis (Falchuk et al., 1975a) and that the degree of increase provided a useful marker of the activity of the disease process (Falchuk et al., 1975b). Several further studies have been published but there is no firm agreement regarding the clinical value of measuring serum lysozyme in inflammatory bowel disease. Most workers find raised values in patients with either Crohn's disease or ulcerative colitis and have not been able to demonstrate a clear-cut relationship with disease activity (Dronfield and Langman, 1975; Pruzanski and Marcon, 1975; Pounder et al., 1975; Hylander et al., 1976; Peeters et al., 1976). It is possible that the differing conclusions of the published reports reflect differences in technique (Peeters et al., 1975) and for this reason we undertook a comparative

1Present address: Manchester Royal Infirmary, Manchester. ${ }^{2}$ Present address: Trinity College, Dublin.

Received for publication 10 October 1977 study of the two methods in common use (lysoplate and turbidometric).

In contrast to the many studies of circulating lysozyme, the concentration of the enzyme in faeces has been the subject of little attention. Many years ago lysozyme was shown to be high in the faeces of patients with inflammatory bowel disease (Meyer et al., 1948; Prudden et al., 1949) and was considered to be a good indicator of disease activity in ulcerative colitis (Gray et al., 1950). There are no similar reports of studies using more refined techniques and so we extended our investigation by applying the lysoplate and turbidometric methods to the measurement of lysozyme in the faeces of patients with inflammatory bowel disease and control subjects.

\section{Methods}

PATIENTS STUDIED

Details of the patients whose serum lysozyme was estimated are shown in Table 1. The diagnosis of each of the 61 patients with inflammatory bowel disease was reached using accepted criteria (LennardJones et al., 1968; Glotzer et al., 1970). Thirty-six 
Table 1 Features of patients studied (serum lysozyme)

\begin{tabular}{|c|c|c|c|c|c|c|c|c|c|}
\hline $\begin{array}{l}\text { Normal (healthy controls) } \\
\text { (no.) }\end{array}$ & $\begin{array}{l}\text { Cro } \\
\text { (no.) }\end{array}$ & & lysoplate) & $\begin{array}{l}\text { Crol } \\
\text { (no.) }\end{array}$ & $h n ' s($ & turbidometric) & $\begin{array}{l}\text { Ulcerative colitis } \\
\text { (no.) }\end{array}$ & $\begin{array}{l}\text { Non-IBD } \\
\text { GI disease } \\
\text { (no.) }\end{array}$ & $\begin{array}{l}\text { Non-GI } \\
\text { disease } \\
\text { (no.) }\end{array}$ \\
\hline \multirow[t]{3}{*}{29} & 34 & & & 36 & & & 25 & 20 & 20 \\
\hline & SB & LB & $\mathbf{S B}+\mathbf{L B}$ & SB & LB & $\mathbf{S B}+\mathbf{L B}$ & Pancolitis 12 & & \\
\hline & 7 & 6 & 21 & 8 & 6 & 22 & Left-sided 13 & & \\
\hline
\end{tabular}

SB: small bowel. LB: large bowel.

had Crohn's disease and 25 ulcerative colitis. The assessment of severity (severe, moderate/mild, in remission) of Crohn's disease was based on the classification of de Dombal et al. (1974). The 20 patients without gastrointestinal disease had cardiovascular, pulmonary, neurological, and hepatic disorders and apparently normal stools. The group of 20 patients with gastrointestinal disease other than inflammatory bowel disease was composed of five with irritable bowel syndrome, four with peptic ulceration, three with post-gastrectomy diarrhoea, two with coeliac disease, one with ileocaecal tuberculosis, one with diverticular abscesses, one with intestinal lymphangiectasia, one with chronic pancreatitis, one with Gardner's syndrome, and one with the 'short bowel syndrome' following resection.

Details of the patients whose faeces were studied are shown in Table 2. Faecal lysozyme was measured in 27 patients with active Crohn's disease and 13 with ulcerative colitis. The 30 patients without gastrointestinal disease were classified as in the studies of circulating lysozyme. The 27 patients with non-inflammatory gastrointestinal disease

Table 2 Features of patients studied (faecal lysozyme)

\begin{tabular}{|c|c|c|c|c|}
\hline $\begin{array}{l}\text { Normal } \\
\text { (healthy } \\
\text { controls) } \\
\text { (no.) }\end{array}$ & $\begin{array}{l}\text { Active } \\
\text { Crohn's } \\
\text { (no.) }\end{array}$ & $\begin{array}{l}\text { Active } \\
\text { ulcerative } \\
\text { colitis } \\
\text { (no.) }\end{array}$ & $\begin{array}{l}\text { Non-IBD } \\
\text { GI disease } \\
\text { (no.) }\end{array}$ & $\begin{array}{l}\begin{array}{l}\text { Non-GI } \\
\text { disease }\end{array} \\
\text { (no.) }\end{array}$ \\
\hline 11 & $\begin{array}{l}27 \\
21 \text { with diarrhoea } \\
6 \text { without }\end{array}$ & 13 & $\begin{array}{l}27 \\
18 \text { with diarrhoea } \\
9 \text { without }\end{array}$ & 30 \\
\hline
\end{tabular}

consisted of eight with antibiotic-induced diarrhoea, five with intestinal lymphoma (four with diarrhoea), four with coeliac disease (one with diarrhoea), three with post-gastrectomy symptoms (two with diarrhoea), two with irritable bowel syndrome (without diarrhoea), one each with thyrotoxicosis, chronic pancreatitis, and diabetes mellitus(all with diarrhoea), and one each with giardiasis and 'short bowel syndrome' after resection (without diarrhoea). A wet stool weight above $300 \mathrm{~g}$ per day, or any weight below this figure where the stool was entirely liquid, was classified as diarrhoea.
LYSOZYME ESTIMATIONS

\section{Serum}

Serum was separated from blood and either assayed immediately or stored for short periods (up to two weeks) at $-20^{\circ} \mathrm{C}$ and then assayed after thawing only once.

In the turbidometric assay, a suspension of killed Micrococcus lysodeikticus (Difco) was made up in $67 \mathrm{mM}$ phosphate buffer at $\mathrm{pH} 6.2$ to achieve a concentration of $0.25 \mathrm{~g} / \mathrm{l}$. To $2.5 \mathrm{ml}$ of this suspension was added $0.1 \mathrm{ml}$ test serum and the fall in optical density recorded at $37^{\circ} \mathrm{C}$ on a Unicam SP8000 spectrophotometer. The activity obtained was compared with that obtained using standard (5-20 $\mu \mathrm{g} / \mathrm{ml}$ ) concentrations of egg white lysozyme (Sigma). The standard curve is linear up to $20 \mu \mathrm{g} / \mathrm{ml}$; samples above this limit are brought into the range by dilution. The lysoplate assay was based on the published method of Osserman and Lawlor (1966). Micrococcus lysodeikticus in $67 \mathrm{mM}$ phosphate buffer at $\mathrm{pH} 6.2$ was added to molten $1 \%$ agarose (Serevac) to give a final concentration of Micrococcus lysodeikticus of $0.5 \mathrm{~g} / \mathrm{l}$. This was poured into circular plastic dishes to a depth of $4 \mathrm{~mm}$ and wells of $3 \mathrm{~mm}$ in diameter were cut out of the agar. Test serum $(20 \mu \mathrm{l})$ or standard egg white lysozyme solution $(5-500 \mu \mathrm{g} / \mathrm{ml})$ were placed in each well and left overnight at room temperature. The lytic circles around each well were measured with a Bausch and Lomb measuring magnifier. The serum values were obtained from the standard (semilogarithmic) curve.

\section{Faeces}

Stools were thoroughly homogenised and aliquots were stored at $-20^{\circ} \mathrm{C}$ until assay. To $1 \mathrm{~g}$ of frozen stool was added $10 \mathrm{ml}$ decinormal hydrochloric acid. The resulting suspension was thoroughly triturated and spun at $40000 \mathrm{~g}$ for 30 minutes. The supernatant was decanted and assayed for lysozyme by the two methods described above.

\section{Statistical methods}

The significance of differences in serum lysozyme levels was tested by Student's $t$ test. The significance 
of differences in faecal lysozyme levels was tested using the Wilcoxon rank sum test.

\section{Results}

\section{SERUM LYSOZYME}

The lysozyme levels obtained by the two methods are shown in Fig. 1. Using the lysoplate method, the mean level $(\mu \mathrm{g} / \mathrm{ml} \pm \mathrm{SD})$ in patients with active Crohn's disease was $60 \cdot 1 \pm 30 \cdot 7$ which was significantly $(P<0.001)$ higher than the mean values in healthy control subjects $(27 \cdot 4 \pm 17 \cdot 5)$, patients with no gastrointestinal disease $(30 \cdot 1 \pm 16 \cdot 8)$ and gastrointestinal patients without inflammatory bowel disease $(27.8 \pm 12.8)$, and significantly $(P<0.005)$ higher than the mean level in patients with ulcerative colitis $(30.5 \pm 17 \cdot 1)$. The mean level in ulcerative colitis was significantly different only from that in patients with Crohn's disease $(P<0.005)$. The mean level $(\mu \mathrm{g} / \mathrm{ml} \pm \mathrm{SD})$ as measured by the turbidometric method in patients with active Crohn's disease was $9 \cdot 2 \pm 2 \cdot 7$, which was significantly higher $(\mathrm{P}<0.001)$ than the mean levels $(\mu \mathrm{g} / \mathrm{ml} \pm \mathrm{SD})$ in all other groups: healthy controls $4.4 \pm 2.0$; patients with active ulcerative colitis 7.3 \pm 1.5 ; non-gastrointestinal patients $5.9 \pm 2.7$; and gastrointestinal patients without inflammatory bowel disease $6 \cdot 1 \pm 2 \cdot 2$. Also, the mean level in patients with active ulcerative colitis was significantly different from mean values in all other groups $(P<0.001)$. Of the two methods of measurement, the turbidometric technique showed a more clearcut distinction between lysozyme values in active Crohn's disease and those in healthy controls.
With the lysoplaie technique, the mean lysozyme level $(\mu \mathrm{g} / \mathrm{ml} \pm \mathrm{SD})$ for groups of patients with inflammatory disease subdivided according to disease activity (Fig. 2) was as follows: normal controls $27.4 \pm 17 \cdot 5$; severe Crohn's disease $94.6 \pm$ 16.1; moderate/mild Crohn's disease 40.0 \pm 19.5 ; quiescent Crohn's disease 23.7 \pm 13.3 ; active ulcerative colitis $30 \cdot 5 \pm 17 \cdot 1$; quiescent ulcerative colitis $24.0 \pm 11 \cdot 1$. The mean values for patients with severe and moderate/mild Crohn's disease were significantly higher than the mean level of the normal control group $(P<0.001$ and $P<0.025$ respectively). A significantly higher mean level $(P<0.001)$ was found in the severe Crohn's category than in the moderate/mild and quiescent Crohn's categories. The mean level in the moderate/mild group was significantly higher than that in the quiescent group $(P<0.01)$. There was no significant difference between the mean value of the quiescent group and that of the normal controls. There was no overlap between values in patients with severe disease and normal controls. The mean levels in the active and quiescent colitis categories were significantly lower than the level in the severe Crohn's category $(P<0.001)$. Neither ulcerative colitis group was significantly different from each other or from healthy controls.

With the use of the turbidometric method, the mean lysozyme level $(\mu \mathrm{g} / \mathrm{ml} \pm \mathrm{SD})$ for each group was as follows: normal controls $4.4 \pm 2.0$; severe Crohn's disease 10.4 $\pm 1 \cdot 2$; moderate/mild Crohn's disease $8.6 \pm 2.8$; quiescent Crohn's disease 7.3 \pm $2 \cdot 3$; active ulcerative colitis $7 \cdot 3 \pm 1 \cdot 5$; quiescent ulcerative colitis $7 \cdot 1 \pm 2 \cdot 7$. The mean values for all

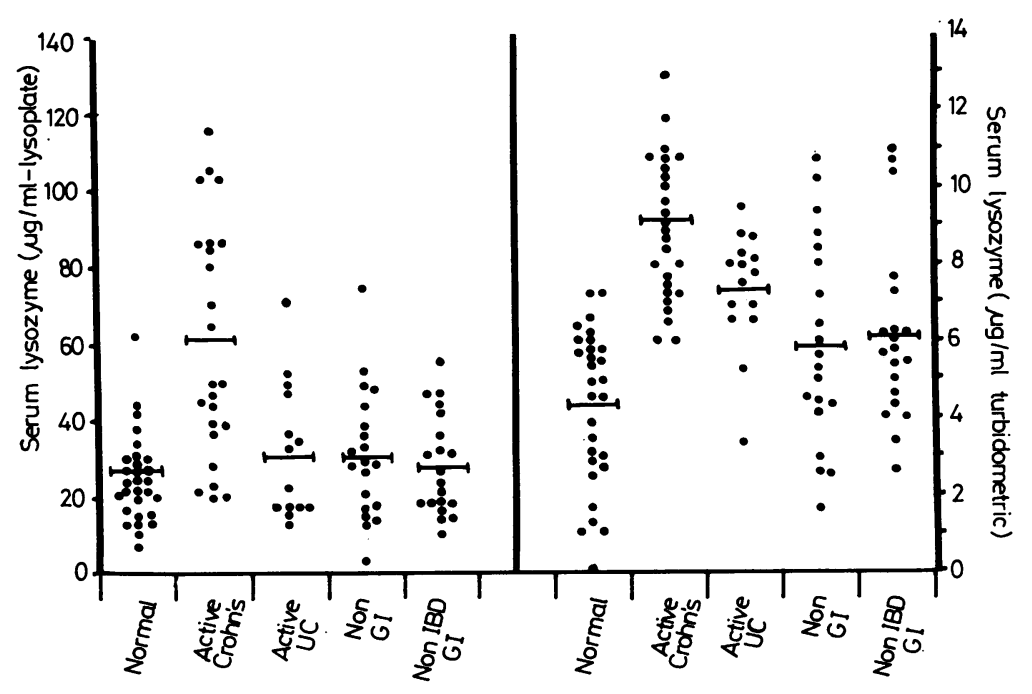

Fig. 1 Serum lysozyme (and mean) in normal volunteers, controls and patients with inflammatory bowel disease. 


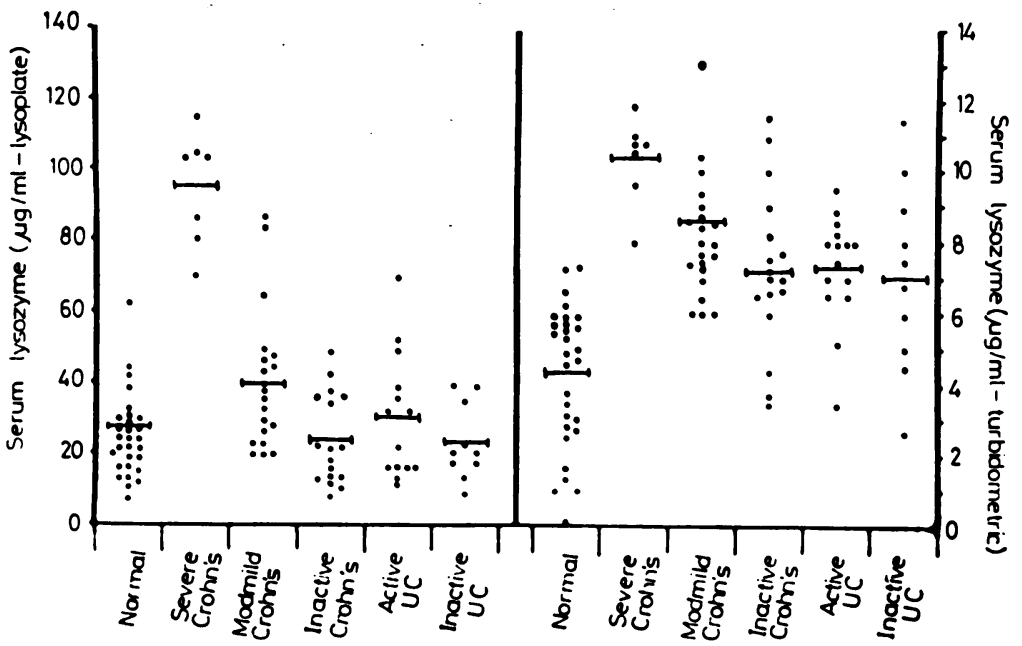

Fig. 2 Serum lysozyme (and mean) in normal volunteers and patients with inflammatory bowel disease.

categories of Crohn's disease were significantly higher than the mean level of the normal control group $(P<0.001)$. Again, there was no overlap between values in patients with severe Crohn's disease and those in healthy controls. The only significant difference among the Crohn's categories was between the mean levels in the severe and quiescent groups $(P<0.005)$. The mean levels obtained in patients with active and quiescent ulcerative colitis were significantly higher than the levels in healthy controls $(P<0.001$ and $P<0.005$ respectively) and significantly lower than in the group of patients with severe Crohn's disease (both $P<0.001)$. There was no significant difference between mean levels in the two groups of patients with ulcerative colitis.

In nine patients with Crohn's disease (Fig. 3) serial lysozyme measurements at different stages of disease showed significant alteration in accordance with disease activity $(P<0.001$ by lysoplate tech-

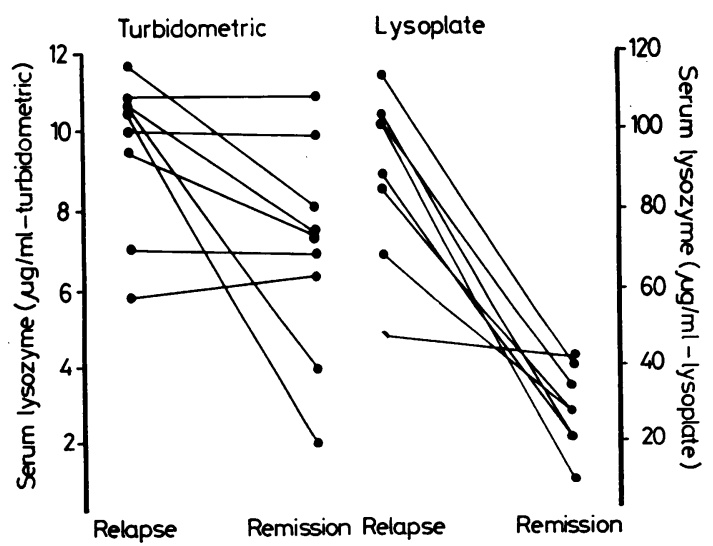

Fig. 3 Serial changes in serum lysozyme. nique and $P<0.05$ by turbidometric technique). The lysoplate values returned to normal in remission; the turbidometric values did not.

The correlation coefficients $(r)$ and significance levels (P) for the results obtained by the two assays were as follows: all patients and normal controls, $r=0.559, \mathrm{P}<0.001 ;$ Crohn's disease patients alone, $r=0.442, \mathrm{P}<0.001$; ulcerative colitis patients alone, $r=0.379, \mathrm{P}<0.05$; patients with non-inflammatory gastrointestinal disease alone, $r$ $=0.359, \mathrm{P}>0.05$; patients without gastrointestinal disease alone, $r=0.561, \mathrm{P}<0.01$; normal controls alone, $r=0.212$, $\mathrm{P}>0.05$.

\section{FAECAL LYSOZYME}

The faecal lysozyme content is shown in Table 3. By both techniques of estimation the mean concentration in all patients with diarrhoea (Crohn's disease with diarrhoea, ulcerative colitis, and noninflammatory bowel disease with diarrhoea) were significantly higher than those obtained in three of the four categories of patients without diarrhoeathat is, healthy controls, patients with non-inflammatory bowel disease without diarrhoea, and patients with no gastrointestinal disease $(P<0.01)$. There was no significant difference between the mean value in patients with Crohn's disease without diarrhoea and that in any other group of patients as measured by the turbidometric technique. It was, however, significantly higher $(P<0.05)$ than the mean level in the healthy controls. Using the lysoplate technique, the mean value in the Crohn's disease patients without diarrhoea was significantly higher than that in healthy controls $(\mathrm{P}<0.01)$, in non-gastrointestinal patients $(P<0.01)$, and inpatients with non-inflammatory bowel disease without diarrhoea $(P<0.05)$ but not significantly 
Table 3 Faecal lysozyme (mean and range)

\begin{tabular}{|c|c|c|c|c|c|c|c|}
\hline Number of patients: & $\begin{array}{l}\text { Crohn's with } \\
\text { diarrhoea } \\
(21)\end{array}$ & $\begin{array}{l}\text { Crohn's without } \\
\text { diarrhoea } \\
\text { (6) }\end{array}$ & $\begin{array}{l}\text { Ulcerative } \\
\text { colitis } \\
\text { (13) }\end{array}$ & $\begin{array}{l}\text { Non-IBD GI } \\
\text { disease with } \\
\text { diarrhoea } \\
(18)\end{array}$ & $\begin{array}{l}\text { Non-IBD G.I. } \\
\text { disease without } \\
\text { diarrhoea } \\
(9)\end{array}$ & $\begin{array}{l}\text { Non-GI } \\
\text { disease } \\
(30)\end{array}$ & $\begin{array}{l}\text { Healthy } \\
\text { controls } \\
\text { (11) }\end{array}$ \\
\hline \multicolumn{8}{|l|}{ Lysoplate } \\
\hline $\begin{array}{l}\text { Concn. } \\
(\mu g / g \text { wet } w t)\end{array}$ & $\begin{array}{l}941 \cdot 4 \\
0-1800\end{array}$ & $\begin{array}{l}79 \cdot 3 \\
0-260\end{array}$ & $\begin{array}{l}585 \cdot 8 \\
10-1800\end{array}$ & $\begin{array}{l}256 \cdot 1 \\
10-1000\end{array}$ & $\begin{array}{l}21 \cdot 7 \\
0-75\end{array}$ & $\begin{array}{l}22 \cdot 3 \\
0-90\end{array}$ & 0 \\
\hline $\begin{array}{l}\text { Total daily content } \\
\quad(\mu \mathrm{g})\end{array}$ & $\begin{array}{l}18.3 \times 10^{4} \\
0-99.7 \times 10^{4}\end{array}$ & $\begin{array}{l}1.4 \times 10^{4} \\
0.4 \cdot 2 \times 10^{4}\end{array}$ & $\begin{array}{l}16.7 \times 10^{4} \\
0.13 \times 10^{4}- \\
58.5 \times 10^{4}\end{array}$ & $\begin{array}{l}6.3 \times 10^{4} \\
0.43 \times 10^{4}- \\
30.0 \times 10^{4}\end{array}$ & $\begin{array}{l}0.29 \times 10^{4} \\
0-0.90 \times 10^{4}\end{array}$ & $\begin{array}{l}0.13 \times 10^{4} \\
0.1 .5 \times 10^{4}\end{array}$ & 0 \\
\hline \multicolumn{8}{|l|}{ Turbidometric } \\
\hline $\begin{array}{l}\text { Concn. } \\
(\mu \mathrm{g} / \mathrm{g} \text { wet wt })\end{array}$ & $\begin{array}{l}89 \cdot 8 \\
0-384\end{array}$ & $\begin{array}{l}47 \cdot 0 \\
0-104\end{array}$ & $\begin{array}{l}116 \cdot 2 \\
0-218\end{array}$ & $\begin{array}{l}89 \cdot 1 \\
0-298\end{array}$ & $\begin{array}{l}18 \cdot 7 \\
0-66\end{array}$ & $\begin{array}{l}19 \cdot 5 \\
0-60\end{array}$ & 0 \\
\hline $\begin{array}{l}\text { Total daily content } \\
\quad(\mu \mathrm{g})\end{array}$ & $\begin{array}{l}2.9 \times 10^{4} \\
0-11.9 \times 10^{4}\end{array}$ & $\begin{array}{l}0.56 \times 10^{4} \\
0-1.7 \times 10^{4}\end{array}$ & $\begin{array}{l}3.4 \times 10^{4} \\
0.9 \cdot 1 \times 10^{4}\end{array}$ & $\begin{array}{l}1.4 \times 10^{4} \\
0.5 .9 \times 10^{4}\end{array}$ & $\begin{array}{l}0.26 \times 10^{4} \\
0-0.95 \times 10^{4}\end{array}$ & $\begin{array}{l}0.18 \times 10^{4} \\
0-1 \cdot 1 \times 10^{4}\end{array}$ & 0 \\
\hline
\end{tabular}

different from the diarrhoeal categories. There were no significant differences between mean concentrations as measured by either technique in any of the groups with diarrhoea.

By both techniques, the mean daily faecal lysozyme outputs in all patients with diarrhoea were significantly higher than those in healthy controls, patients with non-inflammatory bowel disease without diarrhoea, and patients with no gastrointestinal disease $(P<0.01)$. The mean value in patients with Crohn's disease without diarrhoea was significantly $(P<0.05)$ lower than that in patients with ulcerative colitis, as measured turbidometrically, but not significantly different from that in any other group of patients or in healthy controls. With the use of the lysoplate technique, the mean value in the Crohn's disease patients without diarrhoea was significantly higher than that in healthy controls $(P<0.02)$ and in non-gastrointestinal patients $(P<0.05)$ and significantly lower than that in patients with Crohn's disease with diarrhoea $(P<0.05)$ and in patients with ulcerative colitis $(\mathrm{P}<0.02)$. Again, there were no significant differences between mean levels in any of the groups with diarrhoea, measured by both techniques.

In neither those patients with inflammatory bowel disease with diarrhoea nor those with non-inflammatory disease of the bowel with diarrhoea does faecal lysozyme concentration correlate with stool weight (Figs. 4 and 5).

\section{Discussion}

Using egg white lysozyme as standard, we have again shown the discrepancy that exists between values of serum lysozyme as measured by the two techniques (Hansen, 1974). Moreover, in the study of patients with inflammatory bowel disease we have shown that the correlation between values obtained by the lysoplate technique and those given by the turbido- metric method is not a good one. This conclusion has two important implications.

Firstly, it helps to explain some of the disparities in the results of studies of serum lysozyme reported from other centres. Previously, in this laboratory using the turbidometric technique we found no clear distinction between estimations made on the serum of patients suffering from inflammatory bowel disease and those of normal controls (Kane et al., 1974). In this second study, we confirm our previous observations, but using the lysoplate technique achieve results which correspond more closely to those of Falchuk et al. (1975a, b). Patients with severe Crohn's disease differ markedly from normal; those with ulcerative colitis do not. Even so, in the present series, serum lysozyme levels in patients with the less severe forms of Crohn's disease do not differ from normal. As a corollary, it would seem possible to follow the progress of patients with Crohn's disease using serum lysozyme (lysoplate) but not by serum lysozyme (turbidometric) (Fig. 3).

The second implication is theoretical. Serum lysozyme values are considerably greater using the lysoplate technique. This suggests that there is a factor in serum which is either inhibitory in the turbidometric solution or facilitatory in the gel. Moreover, this factor operates to a greater degree in the severer forms of Crohn's disease than it does in the other groups of patients studied. Further study of this problem would be of interest (Peeters and Vantrappen, 1977). No evidence supporting the presence of a rapidly diffusing lysozyme isoenzyme in Crohn's disease has yet been adduced (Peeters et al., 1976).

The increased circulating lysozyme in patients with granulomatous diseases may be derived from tissue macrophages which can be shown histochemically to contain the enzyme (Mason and Taylor, 1975). Macrophages, unlike granulocytes, synthesise and secrete lysozyme continuously 


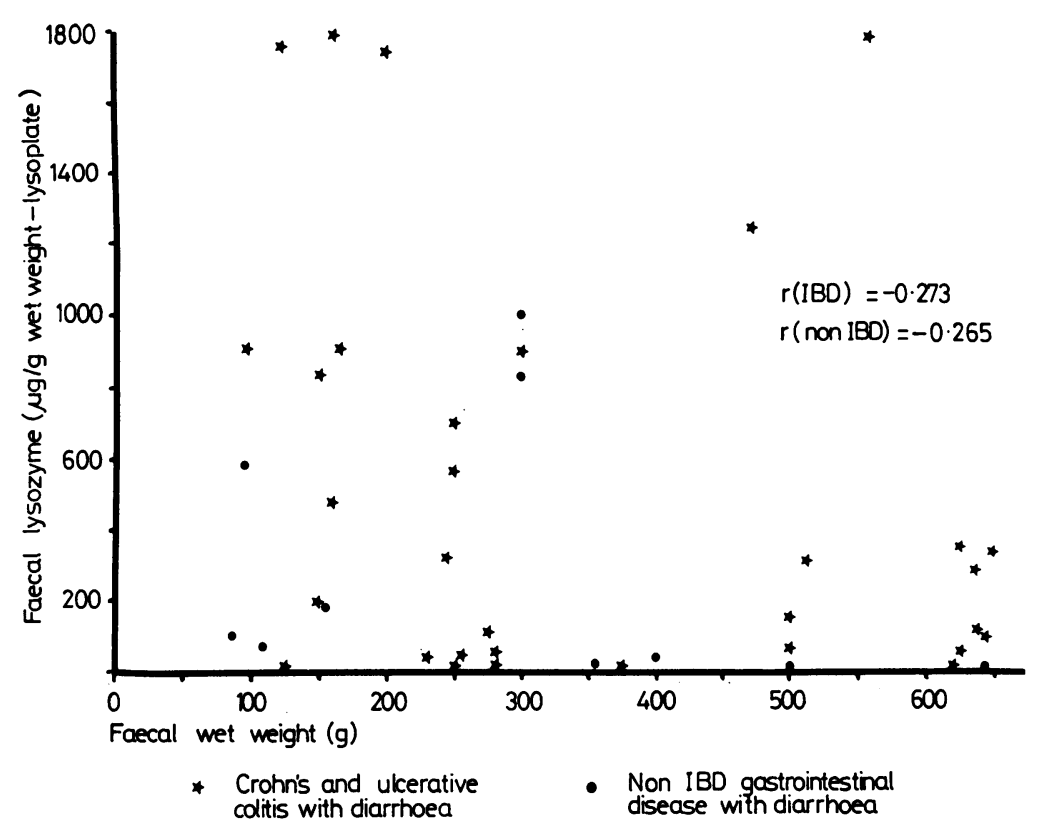

Fig. 4 Correlation between faecal lysozyme (measured by lysoplate technique) and faecal wet weight.

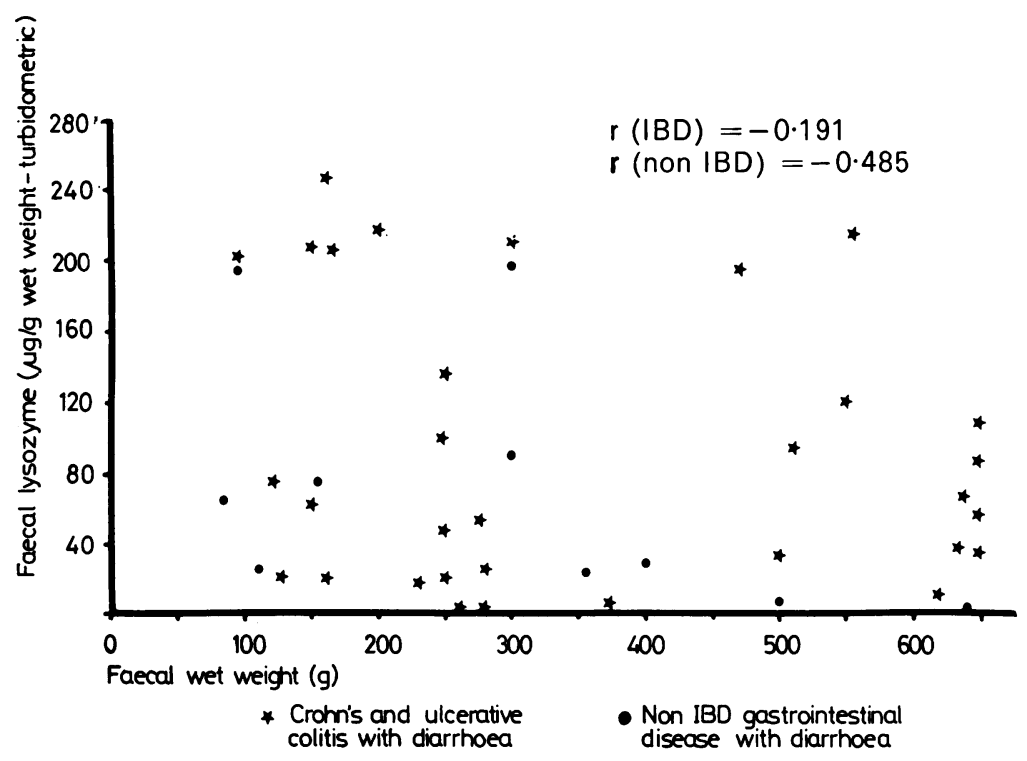

Fig. 5 Correlation between faecal lysozyme (measured by turbidometric technique) and faecal wet weight.

(Gordon et al., 1974; McClelland and van Furth, 1975) and increased lysozyme synthesis has been demonstrated in Crohn's disease tissue (McClelland et al., 1976).

On the other hand, cells of the granulocyte and monocyte series are also present in the intestinal mucosa of patients with inflammatory bowel disease, particularly those with ulcerative colitis (Anthonisen and Riis, 1962; Levine and Engle, 1969; Riis and Anthonisen, 1971). They contain lysozyme (Klockars et al., 1977) and probably contribute to the lysozyme content of the mucosa by releasing the enzyme as they degranulate (Fink and Finch, 1968). Paneth cells also contain and can secrete lysozyme (Peeters and Vantrappen, 1975); the Paneth cell population is increased in Crohn's disease (Lewin, 1969), and 
Paneth cell metaplasia is a common finding in ulcerative colitis. Colonic mucosal crypt cells in ulcerative colitis have also been shown to contain lysozyme (Klockars et al., 1977). It is possible that lysozyme from these various sources is secreted or diffuses into the systemic circulation and into the bowel lumen.

The high concentration of lysozyme in the faeces of patients with inflammatory bowel disease causing diarrhoea may represent the lysozyme secreted into the bowel lumen by active mucosal cells. On the other hand, the high faecal levels found in patients with diarrhoea without associated inflammation suggests that the passage of loose stools exerts a non-specific effect on the excretion of lysozyme. The more rapid evacuation of stools may inhibit the degradation of lysozyme secreted into the lumen of the bowel. Alternatively, factors associated with watery faeces may have a local effect on the bowel mucosa and the release of lysozyme. This latter explanation is supported by the finding of granulocytes in the rectal mucosa of normal subjects given laxatives and enemata (Anthonisen and Riis, 1962).

The role of lysozyme in gastrointestinal disease remains uncertain but present evidence suggests it is of epiphenomenonal rather than pathogenetic significance in inflammatory bowel disease. The present studies do not suggest it is likely to come into routine use as a diagnostic marker or index of activity in inflammatory bowel disease.

We wish to thank Miss Joan Gray for secretarial assistance, and the nursing staff who helped with the collection of specimens.

\section{References}

Anthonisen, P., and Riis, P. (1962). The cytology of colonic secretion in proctosigmoidal disease. Acta Medica Scandinavica, 172, 375-381.

de Dombal, F. T., Burton, I. L., Clamp, S. E., and Goligher, J. C. (1974). Short term course and prognosis of Crohn's disease. Gut, 15, 435-443.

Dronfield, M. W., and Langman, M. J. S. (1975). Serum lysozyme in inflammatory bowel disease. Gut, 16, 985-987.

Falchuk, K. R., Perrotto, J. L.; and Isselbacher, K. J. (1975a). Serum lysozyme in Crohn's disease and ulcerative colitis. New England Journal of Medicine, 292, 395-397.

Falchuk, K. R., Perrotto, J. L., and Isselbacher, K. J. (1975b). Serum lysozyme in Crohn's disease. Gastroenterology, 69, 893-896.

Fink, M. E., and Finch, S. C. (1968). Serum muramidase and granulocyte turnover. Proceedings of Society for Experimental Biology and Medicine, 127, 365-367.

Glotzer, D. J., Gardner, R. C., Goldman, H., Hinrichs, H. R., Rosen, H., and Zetzel, L. (1970). Comparative features and course of ulcerative and granulomatous colitis. New England Journal of Medicine, 282, 582-587.

Gordon, S., Todd, J., and Cohn, Z. A. (1974). In vitro synthesis and secretion of lysozyme by mononuclear phagocytes. Journal of Experimental Medicine, 139,
1228-1248.

Gray, S. J., Reifenstein, R. W., Connolly, E. P., Spiro, H. M., and Gordon Young, J. C. (1950). Studies on lysozyme in ulcerative colitis. Gastroenterology, 16, 687-696.

Hansen, N. E. (1974). Lysozyme assay. Series Haematologica, 7, 14-21.

Hylander, E., Hansen, N. E., Karle, H., and Jarnum, S. (1976). Serum lysozyme in Crohn's disease and ulcerative colitis. Scandinavian Journal of Gastroenterology, 11, 213-217.

Kane, S. P., Hoffbrand, A. V., and Neale, G. (1974). Indices of granulocyte activity in inflammatory bowel disease. Gut, 15, 953-959.

Klockars, M., Reitamo, S., Reitamo, J. J., and Möller, C. (1977). Immunohistochemical identification of lysozyme in intestinal lesions in ulcerative colitis and Crohn's disease. Gut, 18, 377-381.

Lennard-Jones, J. E., Lockhart-Mummery, H. E., and Morson, B. C. (1968). Clinical and pathological differentiation of Crohn's disease and proctocolitis. Gastroenterology, 54, 1162-1170.

Levine, M. L., and Engle, R. L., (1969). The granulocytic response in nonspecific ulcerative colitis. American Journal of Digestive Diseases, 14, 69-79.

Lewin, K. (1969). The Paneth cell in disease. Gut, 10, 804-811. Mason, D. Y., and Taylor, C. R. (1975). The distribution of muramidase (lysozyme) in human tissues. Journal of Clinical Pathology, 28, 124-132.

McClelland, D. B. L., and van Furth, R. (1975). In vitro synthesis of lysozyme by human and mouse tissues and leucocytes. Immunology, 28, 1099-1114.

McClelland, D. B. L., Shearman, D. J. C., Lai A Fat, R. F. M., and van Furth, R. (1976). In vitro synthesis of immunoglobulins, secretory component, complement and lysozyme by human gastrointestinal tissues. Clinical and Experimental Immunology, 23, 20-27.

Meyer, K., Gellhorn, A., Lehrman, W., Prudden, J. F., and Steinberg, A. (1948). Lysozyme activity in ulcerative alimentary disease. II. Lysozyme activity in chronic ulcerative colitis. American Journal of Medicine, 5, 496-502.

Osserman, E. F., and Lawlor, D. P. (1966). Serum and urinary lysozyme (muramidase) in monocytic and monomyelocytic leukaemia. Journal of Experimental Medicine, 124, 921-952.

Peeters, T. L., Geboes, K., and Vantrappen, G. R. (1975). Serum lysozyme levels in Crohn's disease (Letter). New England Journal of Medicine, 292, 1349.

Peeters, T. L., and Vantrappen, G. R. (1975). The Paneth cell: a source of intestinal lysozyme. Gut, 16, 553-558.

Peeters, T. L., and Vantrappen, G. R. (1977). Factors influencing lysozyme determinations by the lysoplate method. Clinica Chimica Acta, 74, 217-225.

Peeters, T. L., Vantrappen, G. R., and Geboes, K. (1976). Serum lysozyme levels in Crohn's disease and ulcerative colitis. Gut, 17, 300-305.

Pounder, R. E., Avella, J. R., McCallum, H., and Misiewicz, J. J. (1975). Serum lysozyme in inflammatory bowel disease (Letter). Lancet, 2, 228-229.

Prudden, J. F., Lane, N., and Levison, J. (1949). Lysozyme titres in regional enteritis, miscellaneous tissues, microorganisms, and excreta. Proceedings of the Society for Experimental Biology and Medicine, 72, 220-222.

Pruzanski, W., and Marcon, M. (1975). Lysozyme in Crohn's disease (Letter). New England Journal of Medicine, 293, 611-612.

Riis, P., and Anthonisen, P. (1971). The presence of inflammatory leucocytes in the rectal mucus of patients with regional ileitis. Scandinavian Journal of Gastroenterology, 6, 719-721. 